\title{
PERANCANGAN ULANG MAGNET PENGANALISIS PADA IMPLANTOR ION DENGAN SIMULATOR SUPERFISH DAN OPERA-3D
}

\author{
Taufik, Suprapto, Silakhuddin \\ Pusat Teknologi Akselerator Proses Bahan, BATAN \\ Jl. Babarsari Kotak Pos 6101 ykbb, Yogyakarta 55281 \\ e-mail : taufikis@gmail.com
}

Diterima 18 Juli 2011, diterima dalam bentuk perbaikan 05 September 2011, disetujui 16 Januari 2012

\begin{abstract}
ABSTRAK
PERANCANGAN ULANG MAGNET PENGANALISIS PADA IMPLANTOR ION DENGAN SIMULATOR SUPERFISH dan OPERA-3D. Telah dilakukan perancangan ulang magnet penganalisis pada implantor ion. Agar ion yang diimplantasikan pada suatu target adalah ion tunggal maka diperlukan magnet penganalisis. magnet penganalisis dapat memisahkan ion-ion pengotor dari berkas ion yang dipercepat sehingga dihasilkan ion tunggal. Implantor ion di PTAPB telah dilengkapi dengan magnet penganalisis, tetapi masalahnya adalah data desain detilnya belum ada dan belum berfungsi secara optimal sehingga akan menghambat untuk keperluan perawatan dan pengembangan. Tujuan dari kegiatan ini adalah untuk memperoleh data teknis magnet penganalisis dan melakukan optimasi desain. Untuk mencapai tujuan tersebut, kegiatan diawali dengan mencari pustaka yang berhubungan dengan magnet penganalisis, melakukan perhitungan detil dengan mempertimbangkan parameter yang telah ada, simulasi terhadap desain yang telah dibuat, penentuan parameter desain dan optimasi dari desain yang telah ada. Dari kegiatan ini dapat diperoleh dokumen desain detil magnet penganalisis untuk energi partikel $150 \mathrm{keV}$ dengan sudut pembelokan $60^{\circ}$ serta kemampuan memisahkan partikel dengan $\mathrm{m} / \mathrm{z}=8 \mathrm{amu}$. Sedangkan optimasi dari desain sebelumnya dapat dilakukan dengan mengubah bentuk inti magnet tipe $\mathrm{C}$ menjadi tipe $\mathrm{H}$, mengubah bentuk kutub magnet menjadi segi empat dengan posisi berkas yang masuk membentuk sudut $\theta$ positif dan lebih condong ke tepi kutub magnet.
\end{abstract}

Kata kunci : implantor ion, magnet penganalisis, desain detil, optimasi

\begin{abstract}
REDESIGN OF ANALYZER MAGNET ON ION IMPLANTER USING SUPERFISH and OPERA-3D SIMULATOR. Redesign of analyzer magnet on ion implanter using superfish and opera-3D simulator has been done. In order for the implanted ions on a target is a single ion a magnetic analyzer is needed. The magnetic analyzer can separate some impurity ions from accelerated ion beams to produce a single ion beams. Ion implanter in PTAPB has been equipped with a magnetic analyzer, but the design details data were not available and the functions still were not optimal so that it will hamper for maintenance and development. The purpose of this activity is to obtain a document containing technical information and to optimize a magnetic analyzer design. To achieve these objectives, the activities initiated by searching for references related to the magnetic analyzer, perform detailed calculation with considering the existing parameters, simulation of the design that has been made, determination of design parameters and optimization of the designs. From this activity can be obtained a detailed design document of magnetic analyzer for $150 \mathrm{keV}$ particle energy with $60^{\circ}$ bending angle and the ability to separate particles with $\mathrm{m} / \mathrm{z}=8 \mathrm{amu}$. While the optimization of the previous design can be done by changing the shape of $\mathrm{C}$-type magnetic core into $\mathrm{H}$ type, change the shape of the magnetic pole into a square with the position of incoming beam makes a positive $\theta$ angle and inclined to the edge of the magnetic poles.
\end{abstract}

Keywords: ion implanter, magnetic analyzer, design detail, optimization

\section{PENDAHULUAN}

Demanfaatan implantor ion untuk rekayasa material sudah banyak digunakan dan manfaatnya dapat dirasakan dewasa ini. Implator ion merupakan alat untuk mengimplantasikan ion dopan pada material target sehingga diperoleh karakteristik yang berbeda dari sebelummnya. Salah satu komponen pada implantor ion adalah magnet penganalisis/pemisah(1). Magnet pemisah berfungsi untuk memisahkan ion dopan dari ion-ion lainnya yang tidak diinginkan sehingga ion dopan yang akan diimplantasikan pada material target merupakan ion tunggal.

Saat ini PTAPB memiliki implantor ion yang dibuat sendiri dan telah dilengkapi dengan magnet pemisah. Akan tetapi magnet pemisah tersebut belum memiliki data desain detilnya dan saat ini tidak dapat difungsikan 
secara optimal karena ada komponen yang rusak (kendali catu daya). Data desain detil sangat dibutuhkan untuk keperluan perbaikan dan penyempurnaan karena dengan adanya data desain detil tersebut perbaikan dan penyempurnaan akan tepat sasaran dan cepat. Untuk keperluan ini telah dilakukan desain ulang yang meliputi pembuatan dokumen desain detil magnet penganalisis yang telah ada dan optimasi dari desain sebelumnya. Penelitian ini merupakan bagian dari kegiatan pembuatan basic engineering design package akselerator ion untuk generator ion dan implantor ion yang dilaksanakan pada tahun 2009.

Kegiatan ini memuat tentang perhitungan-perhitungan terhadap dimensi dan kuat medan magnet yang diperlukan sampai pada pembuatan gambar teknik yang dituangkan dalam bentuk dokumen desain detil magnet penganalisis. Simulasi medan magnet dengan program superfish dan opera-3d digunakan untuk mengetahui besar dan distribusi medan magnet yang dihasilkan dari model inti magnet yang dirancang serta untuk mengetahui lintasan berkas partikel. Proses optimasi dengan simulasi dilakukan dengan mengubah-ubah model inti magnet dan posisi awal berkas partikel. Diharapkan dokumen ini dapat dimanfaatkan sebagai acuan dalam perbaikan dan penyempurnaan lebih lanjut sehingga magnet pemisah pada implantor ion dapat dimanfaatkan lebih optimal.

\section{METODOLOGI}

\section{Dasar Desain}

Gerakan partikel bermuatan dapat dipengaruhi oleh medan listrik dan medan magnet. Medan listrik dapat mempercepat dan membelokkan partikel bermuatan sedangkan medan magnet hanya dapat membelokkan gerakan partikel bermuatan yang memiliki energi kinetik. Medan magnet yang diperlukan untuk membelokkan partikel bermuatan tergantung pada energi kinetik, massa $(m)$ dan derajat ionisasi $(z)$ dari partikel bermuatan yang dibelokkan. Karena medan magnet yang diperlukan untuk membelokkan sangat tergantung dengan hal-hal tersebut maka magnet pembelok sering disebut magnet penganalisis yang mampu memisahkan partikel bermuatan sesuai dengan $\mathrm{m} / \mathrm{z}$ dan energinya. Fungsi magnet panganalisis pada implantor ion adalah untuk menyeleksi dalam rangka memilih ion dopan yang akan diimplantasikan pada target dari ion-ion lainnya yang berasal dari sumber ion, gas sisa, uap oli dan grease berdasarkan $\mathrm{m} / \mathrm{z}$ suatu ion. Besar medan magnet yang diperlukan untuk membelokkan partikel bermuatan dirumuskan dengan persamaan (1) sebagai berikut :

$$
B=\frac{1}{R} \sqrt{\frac{2 \cdot m \cdot V}{z \cdot e}}
$$

dengan $B$ adalah besar medan magnet dalam Tesla, $R$ adalah jari jari lintasan dalam meter, $\mathrm{m} / \mathrm{z}$ adalah perbandingan massa partikel dan derajat ionisasi dalam amu, $V$ adalah beda potensial untuk percepatan dalam Volt, e adalah muatan elektron dalam coulomb, apabila jari-jari lintasan dan beda potensial selalu konstan maka nilai $B$ hanya tegantung pada $\mathrm{m} / \mathrm{z}^{(2)}$.

Medan magnet dapat dihasilkan dengan magnet permanen atau dengan elektromagnet. Kelemahan magnet permanen adalah tidak dapat divariasi besar medan magnet yang dihasilkan sehingga hanya bisa menyeleksi satu jenis partikel saja. Untuk elektromagnet besar medan magnet yang dihasilkan dapat divariasi sesuai kebutuhan. Oleh karena itu untuk magnet penganalisis digunakan elektromagnet. Besar jumlah lilitan $(N)$ dan arus listrik ( $I)$ pada elektromagnet dinyatakan dalam persamaan (2) sebagai berikut :

$$
N \cdot I=\frac{B \cdot g}{\mu_{0}}
$$

dengan $g$ adalah lebar celah udara dalam meter $(\mathrm{m})$ dan $\mu_{0}$ adalah permeabilitas udara $=4 \pi \times 10^{-7} \mathrm{~T} \mathrm{~m} / \mathrm{A}$.

Arus yang mengalir pada kawat akan mengalami disipasi daya sehingga terjadi panas pada kumparan dan menjalar ke inti magnet. Besarnya disipasi daya dapat dihitung menggunakan persamaan (3) berikut :

$$
P=I^{2} \cdot R
$$

dengan $I$ adalah arus lilitan $(\mathrm{A})$ dan $R$ adalah tahanan kawat $(\Omega)$. Tahanan kawat dihitung menggunakan persamaan (4) berikut :

$$
R=\rho \frac{l}{A}
$$


dengan / adalah panjang kawat tembaga pada kumparan elektromagnetik $(\mathrm{m}), \rho$ adalah tahanan jenis $(\Omega \mathrm{m})$ dan $A$ adalah luas penampang kawat $\left(\mathrm{m}^{2}\right)$.

Selain fungsi utama magnet sebagai pembelok, berkas partikel yang melalui medan magnet dapat mengalami pemfokusan atau penyebaran. Pemfokusan berkas dapat terjadi karena perbedaan sudut pada tepi magnet atau perubahan medan magnet ke arah radial. Pemfokusan berkas partikel yang terjadi pada tepi magnet tergantung dari kemiringan tepi magnetnya. Apabila sudut $\theta$ yaitu sudut yang dibentuk antara orbit partikel dengan garis normal permukaan tepi bernilai positif maka terjadi pemfokusan pada arah aksial dan penyebaran pada arah radial, demikian juga sebaliknya. Adapun nilai sudut $\theta$ ditentukan seperti pada Gambar 1. Menurut In ${ }^{(3)}$.negative gradient atau penurunan medan magnet ke arah radial pada awalnya memberikan pemfokusan aksial kemudian terjadi penyebaran dan sebaliknya penambahan medan magnet ke arah radial memberikan pemfokusan radial
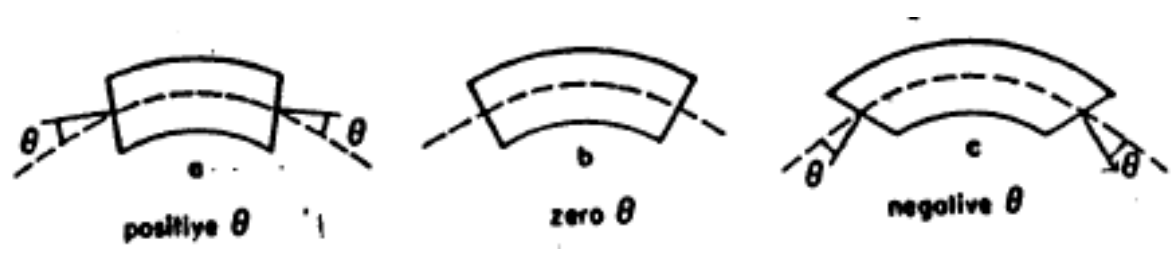

Gambar 1. Pengertian nilai sudut $\theta$.

\section{Langkah Desain}

Dalam mendesain magnet penganalisis, langkah awal yang dilakukan adalah menentukan kriteria desain magnet penganalisis yang meliputi sudut pembelokkan yang digunakan sebesar $60^{\circ}$, jari-jari pembelokkan $R$ sebesar $22,5 \mathrm{~cm}$, perbandingan massa terhadap derajat ionisasi maksimum $(\mathrm{m} / \mathrm{z})$ sebesar 8 amu, energi kinetik partikel yang dibelokkan $150 \mathrm{keV}$ dan celah gap 4,6 cm. Setelah kriteria desain ditentukan langkah berikutnya adalah perhitungan dan simulasi menggunakan program Poison Superfish dan opera-3D dengan modul Tosca.

Superfish adalah kumpulan program yang digunakan untuk perhitungan medan magnet dan medan listrik statik serta medan elektromagnetik RF dalam 2 dimensi. Program Superfish diturunkan dari program perhitungan difusi yang ditulis oleh Alan Winslow di Lawrence Livermore National Laboratory. Program ini membentuk mesh berbentuk segitiga yang dicocokkan dengan batas dari material yang berbeda pada pembentukan geometri. Salah satu program dalam Superfish adalah Poison, yaitu program yang digunakan untuk menghitung medan statik dengan berurutan melalui metode relaksasi (4).

Tosca merupakan salah satu modul dari program Opera-3D yang berbasis elemen hingga. Tosca menggunakan metode elemen hingga diskrit untuk menyelesaikan persamaan diferensial parsial sehingga dapat mengetahui distribusi medan elektromagnetik statik. Tosca didasarkan pada sebuah program dengan nama yang sama yang dikembangkan Rutherford Appleton Laboratory di Inggris. TOSCA dapat digunakan untuk menghitung aliran arus, medan magnet dan medan magnet statik, termasuk pengaruh non-linier media dalam tiga dimensi (4).

Secara garis besar langkah penggunaan program superfish dan opera-3d hampir sama, hanya saja pada superfish simulasi dilakukan dalam 2 dimensi sedangkan pada opera-3d simulasi dilakukan dalam 3 dimensi. Proses diawali dengan pembuatan gambar model berdasarkan kriteria desain yang telah dihitung secara analitis, untuk superfish gambar model dibuat dalam 2 dimensi sedangkan untuk opera-3d gambar model dibuat dalam 3 dimensi. Setelah itu penentuan sifat bahan inti magnet dari gambar model yang dibuat dan proses meshing (membagi model menjadi elemen-elemen kecil). Menurut Beeckman ${ }^{(5)}$ mesh yang lebih kecil ditentukan pada daerah-daerah yang memerlukan ketelitian yang lebih baik. Proses berikutnya adalah perhitungan menggunakan elemen hingga sehingga diperoleh data distribusi medan magnetnya. Pada program opera-3d data distribusi medan magnet yang diperoleh dapat digunakan untuk simulasi berkas partikel dengan energi tetap.

\section{HASIL DAN PEMBAHASAN}

\section{Penentuan Parameter Desain}

Magnet penganalisis pada implantor ion secara umum terdiri dari inti besi lunak untuk menghasilkan fluksi magnet yang optimal, koker lilitan sebagai tempat melilitkan kawat, lilitan kawat (koil) yang dililitkan mengelilingi inti besi lunak untuk dilewati arus listrik DC dan lintasan berkas yang dibelokkan sesuai dengan sudut magnet pembelok. Untuk memenuhi kriteri desain di atas, maka besar medan magnet maksimal yang dibutuhkan dapat dihitung dengan menggunakan persamaan 1 dan diperoleh $B=7014$ gauss. Medan magnet yang diperlukan untuk 
Perancangan ulang magnet penganalisis pada implantor ion dengan simulator superfish dan opera-3D (Taufik, Suprapto, Silakhuddin)

memisahkan partikel bermuatan dengan perubahan $\mathrm{m} / \mathrm{z}$ ditunjukkan pada Gambar 2. Dengan demikian dalam magnet penganalisis diperlukan medan magnet yang dapat divariasikan besar medan magnetnya yaitu antara 0,25 Tesla sampai 0,7 Tesla.

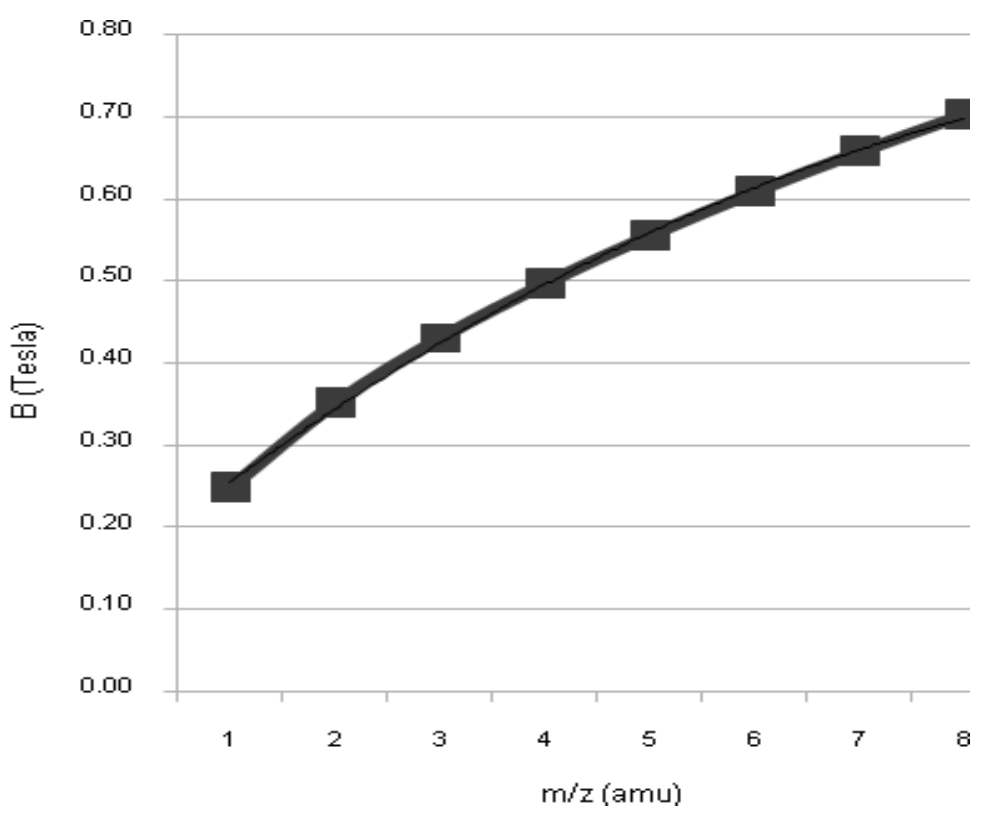

Gambar 2. Pengaruh $\mathrm{m} / \mathrm{z}$ terhadap perubahan medan magnet.

Perhitungan besar arus dalam desain magnet penganalisis ini menggunakan persamaan 2 dengan medan magnet yang digunakan adalah medan magnet maksimal dan lebar celah udara 4,6 cm diperoleh $\mathrm{N}^{\star} \mathrm{I}=25676,87$ ampere lilit. Dalam pembuatan magnet penganalisis, kumparan dibagi menjadi dua kumparan, sehingga $N \cdot I$ masing-masing kumparan adalah $=25.676,87 / 2=12.838,435$ lilit-amper. Apabila masing-masing kumparan dialiri arus $10 \mathrm{~A}$, maka jumlah lilitan masing-masing kumparan dapat ditentukan sebesar $\mathrm{N}=1284$ lilit. Lilitan tersebut disusun secara aksial sebanyak 44 lilit dan secara radial sebanyak 29 lilit seperti pada Gambar 3.

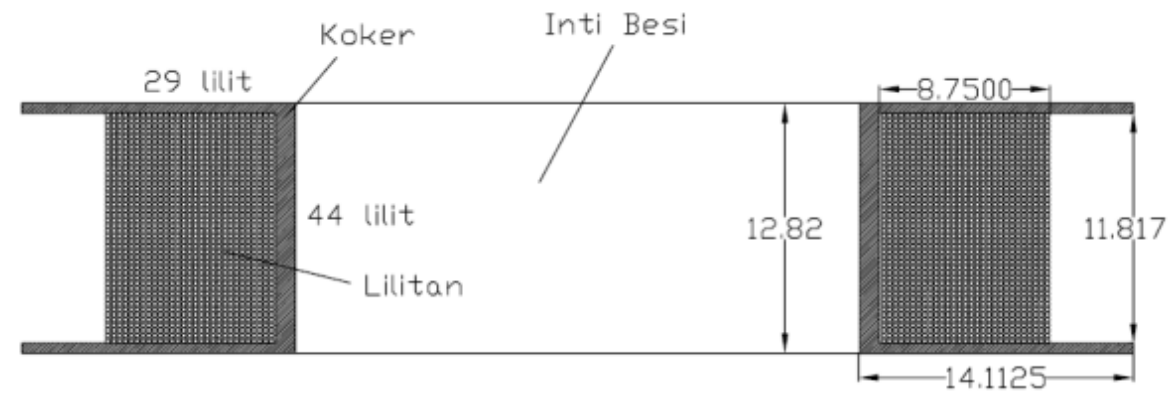

Gambar 3. Dimensi koker dan lilitan kumparan

Kumparan dibuat menggunakan kawat tembaga yang dililitkan pada inti magnet dengan rancangan ukuran inti ditunjukkan pada Gambar 4. Diameter kawat $(D)$ yang digunakan disesuaikan dengan besar arus yang dialirkan dan ditentukan dengan persamaan $D=0,7 \sqrt{I}=0,7 \sqrt{10}=2,2 \mathrm{~mm}$. Agar lebih aman diameter kawat diperbesar menjadi $2,5 \mathrm{~mm}$. Dengan menggunakan data di atas maka diperoleh $A=\frac{1}{4} \pi D^{2}=\frac{1}{4} \pi\left(2,2 \times 10^{-3}\right)^{2}=4,9$ $\times 10^{-6} \mathrm{~m}^{2}, I \approx 1540,8 \mathrm{~m}, \rho=1,95 \times 10^{-8} \Omega \mathrm{m}$, tahanan kedua kumparan dihitung menggunakan persamaan (4) dan diperoleh $12,24 \Omega$, sedangkan disipasi daya yang dihasilkan dari kumparan tersebut dihitung menggunakan persamaan (5) dan diperoleh 1,224 kwatt. 


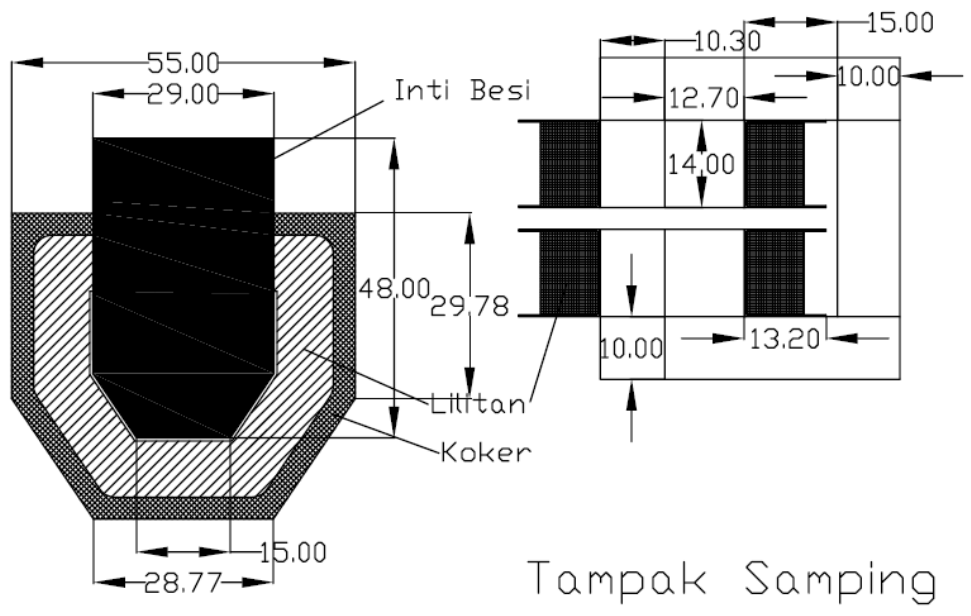

Tampak atas

Gambar 4. Dimensi koker kumparan dan inti magnet

\section{Analisis Dua Dimensi dengan Superfish}

Untuk mengetahui aliran fluksi magnet dan besar medan magnet pada magnet penganalisis dilakukan simulasi dua dimensi dengan menggunakan program superfish. Simulasi dilakukan dengan bahan inti magnet terbuat dari besi dengan kandungan besi $99.91 \%$, permeabilitas realtif maksimal $\left(\mu_{\mathrm{r}}\right)=5000$ dan penjenuhan terjadi pada $B=21500$ gauss ${ }^{(6)}$. Medan magnet yang dihasilkan ditentukan menggunakan bentuk besi seperti huruf $C$ dan permeabilitas relatif yang konstan $\left(\mu_{r}\right)=5000$. Hasil simulasi ditunjukkan pada Gambar 5 dan besar medan magnet pada tengah celah gap ditunjukkan pada Gambar 6 .

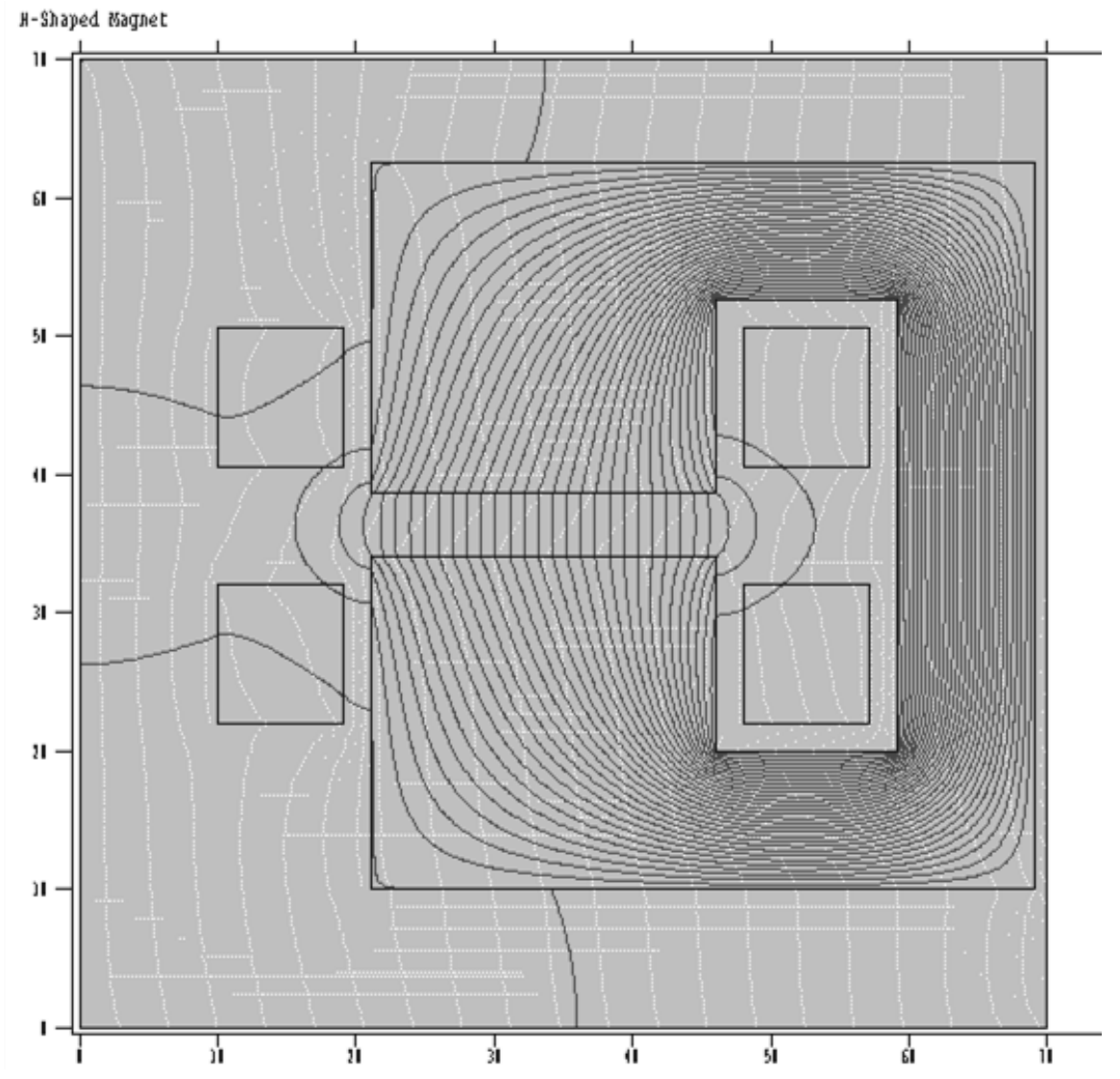

Gambar 5. Distribusi fluks magnet. 


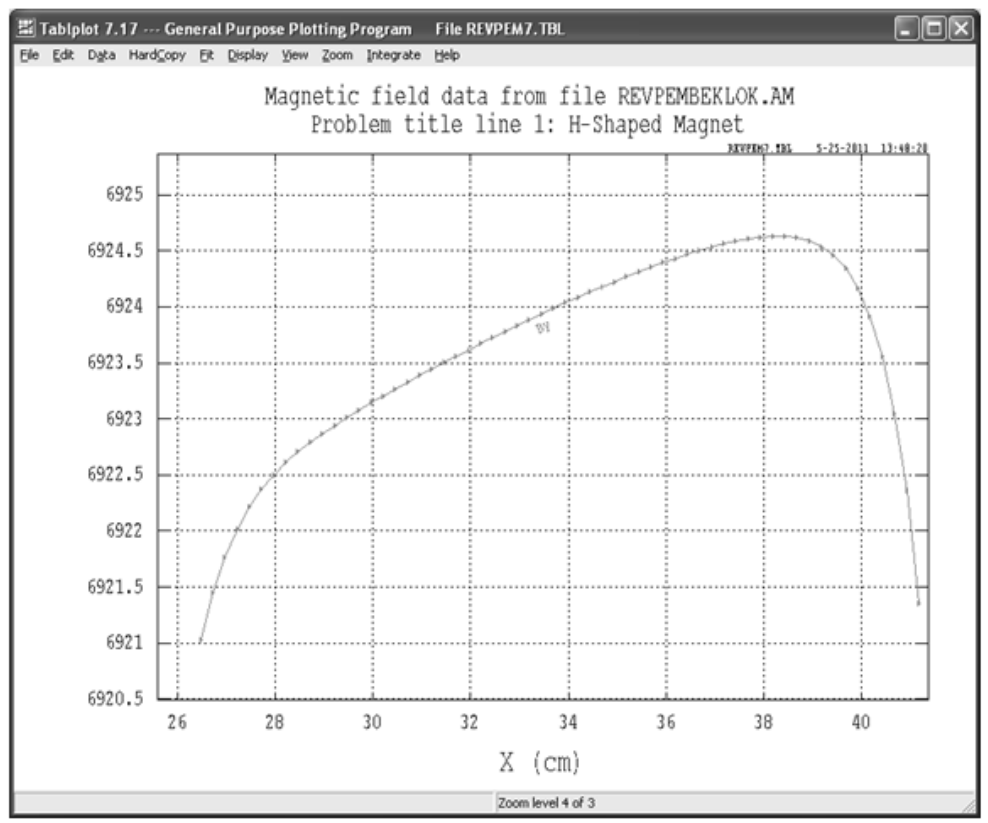

Gambar 6. Besar medan magnet pada tengah celah

Dari Gambar 5 terlihat bahwa garis-garis fluksi pada inti kutub magnet sebelah kiri lebih renggang dibanding pada inti kutub magnet sebelah kanan. Hal ini berarti jika permukaan kutub datar maka semakin ke kanan medan magnet pada celah kutub magnet semakin bertambah yaitu sekitar 4 gauss seperti yang ditunjukkan pada Gambar 6. Dengan perbedaan medan magnet sebesar 4 gauss hanya mengakibatkan penyimpangan jari-jari sebesar 0,2 $\mathrm{mm}$ sehingga penyimpangan ini dapat ditoleransi. Apabila simulasi superfish menggunakan $\mu_{r}=4500$ maka medan magnet mengalami penurunan maksimal sebesar 10 gauss. Hal ini menunjukkan bahwa untuk memperoleh kestabilan medan magnet, parameter yang dapat mengakibatkan perubahan $\mu_{r}$, harus dijaga konstan.

\section{Analisis Tiga Dimensi dengan TOSCA}

Analisis tiga dimensi dilakukan untuk mengetahui distribusi medan magnet dan pengaruhnya terhadap lintasan berkas. Simulasi 2 dimensi tidak dapat memberikan medan yang cukup baik pada daerah yang dipengaruhi oleh efek tepi (7). Untuk itu dilakukan simulasi dengan menggunakan program opera-3D dan modul TOSCA. Dalam simulasi ini digunakan dua bentuk inti magnet yaitu bentuk $\mathrm{C}$ dan bentuk $\mathrm{H}$ seperti ditunjukkan pada Gambar 7 dengan ukuran luas penampang inti yang sama dan menggunakan bahan inti low carbón steel (library tenten.h). Dengan menggunakan $N \cdot I=25.672,8$ lilit amper diperoleh medan magnet maksimal pada bentuk $\mathrm{H}=0,686 \mathrm{~T}$ dan pada bentuk $\mathrm{C}=0,577 \mathrm{~T}$. Dari hasil ini, bentuk inti $\mathrm{H}$ lebih efisien dibandingkan bentuk inti C.

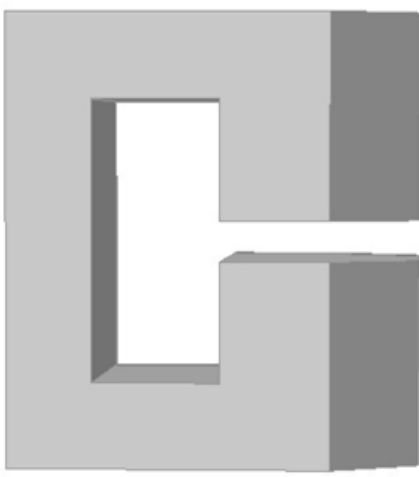

a) Tipe $\mathrm{C}$

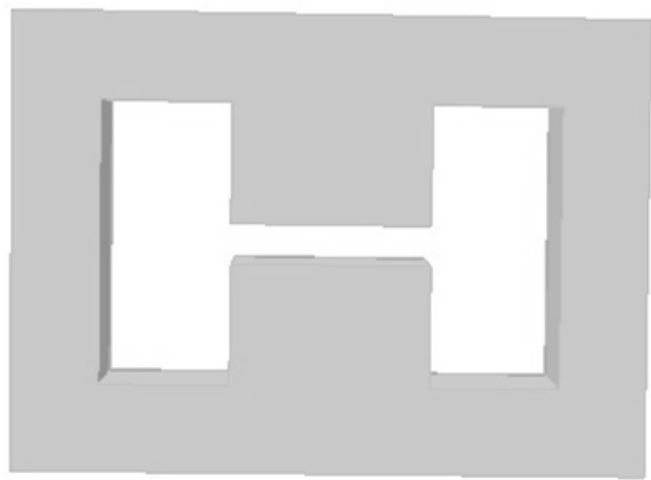

b) Tipe $\mathrm{H}$

Gambar 7. Model inti magnet penganalisis 
Simulasi lintasan berkas dilakukan dengan menggunakan partikel dengan $m / z 8$ amu dan energi partikel 150 $\mathrm{keV}$. Untuk bentuk inti $\mathrm{C}$ dengan bentuk kutub magnet dan arah berkas seperti ditunjukkan pada Gambar 8 , partikel akan mengalami pembelokkan $60^{\circ}$ pada $N \cdot I=25.080$ lilit amper. Berkas partikel yang melewati celah kutub magnet mengalami pemfokusan pada arah radial dan penyebaran pada arah aksial seperti yang ditunjukkan pada Gambar 9 . Hal ini dikarenakan sudut $\theta$ bernilai negative.

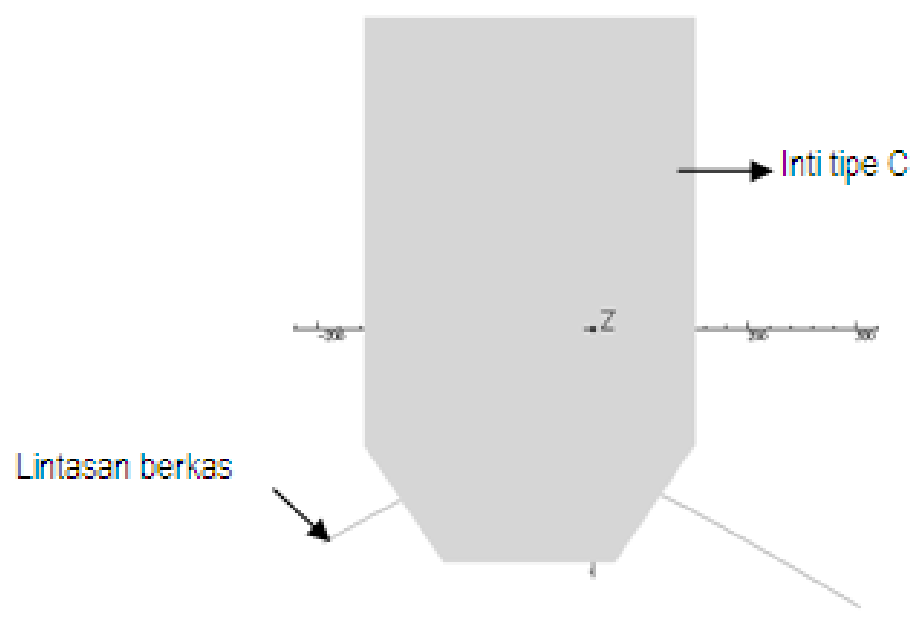

Gambar 8. Simulasi arah lintasan berkas pada inti tipe C

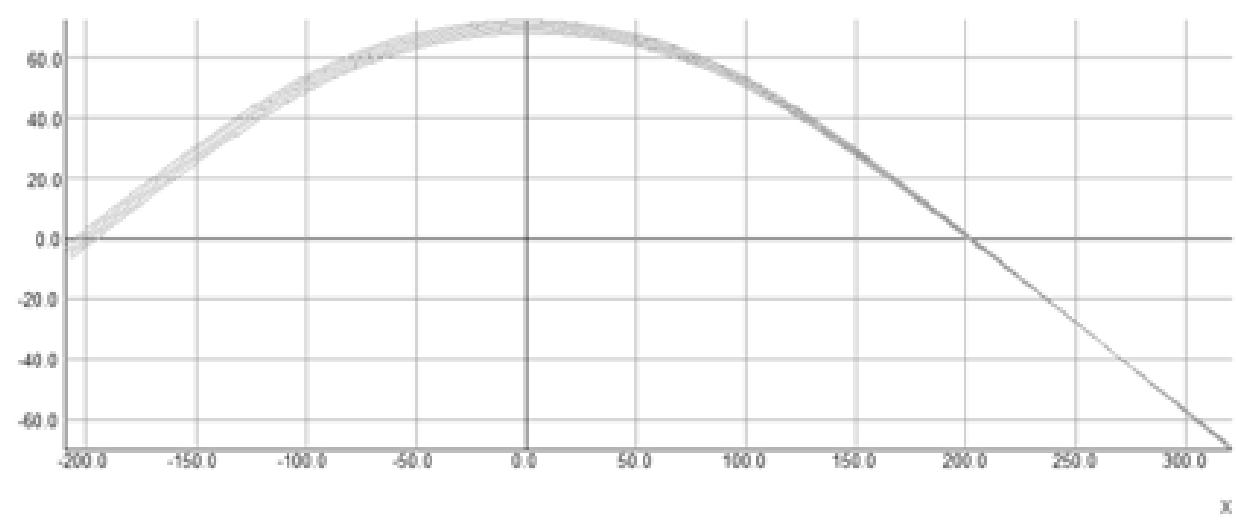

(a) Pemfokusan berkas radial

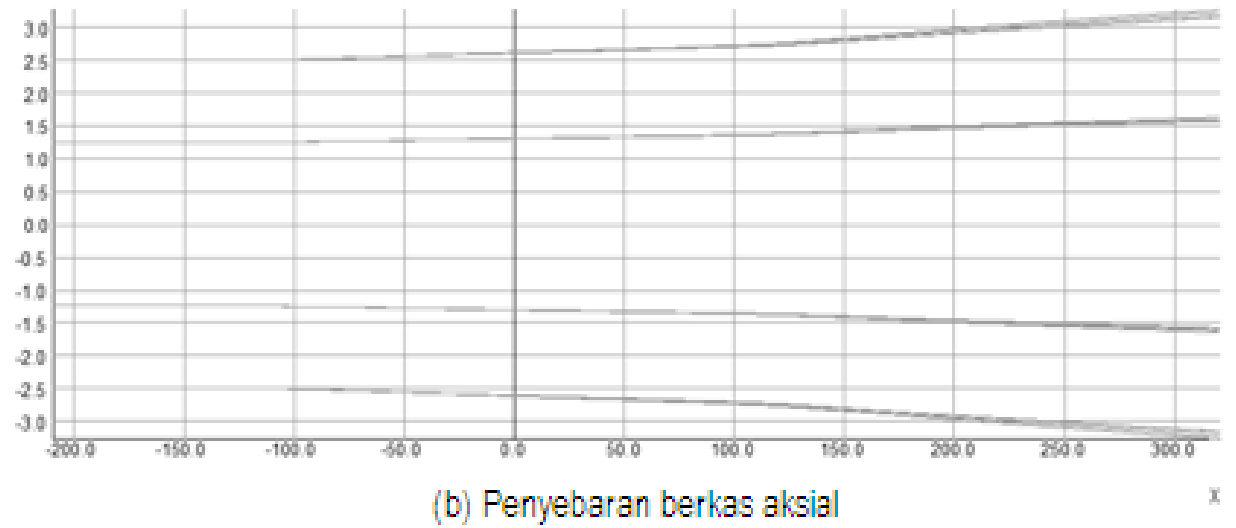

Gambar 9. Pemfokusan berkas pada inti tipe C

Sedangkan simulasi lintasan berkas pada bentuk inti $\mathrm{H}$ dengan bentuk kutub magnet segi empat dan arah berkas seperti ditunjukkan pada Gambar 10 , partikel akan mengalami pembelokan $60^{\circ}$ pada $N \cdot I=18.872$ lilit amper. 
Perancangan ulang magnet penganalisis pada implantor ion dengan simulator superfish dan opera-3D (Taufik, Suprapto, Silakhuddin)

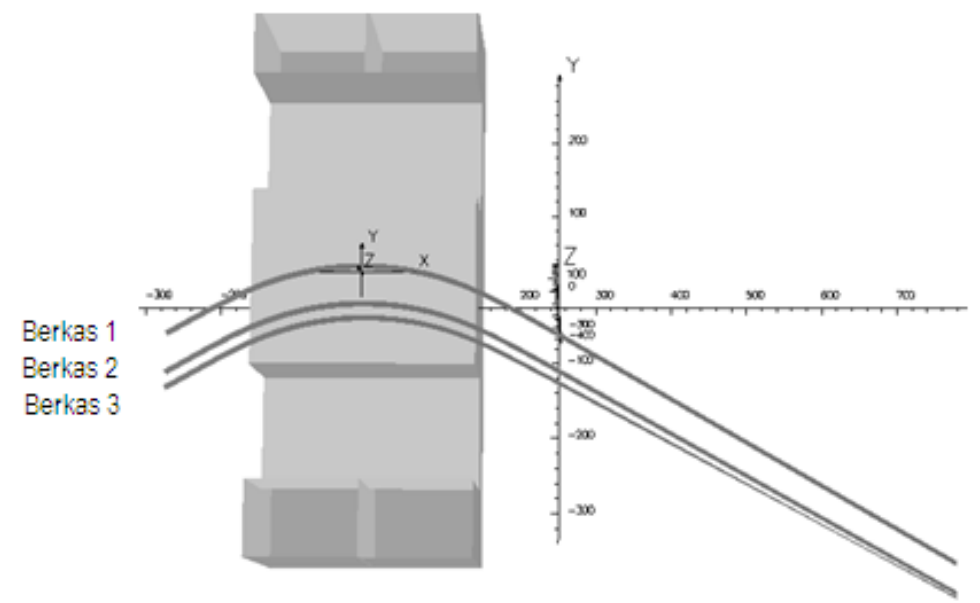

Gambar 10. Simulasi arah lintasan berkas pada inti tipe H

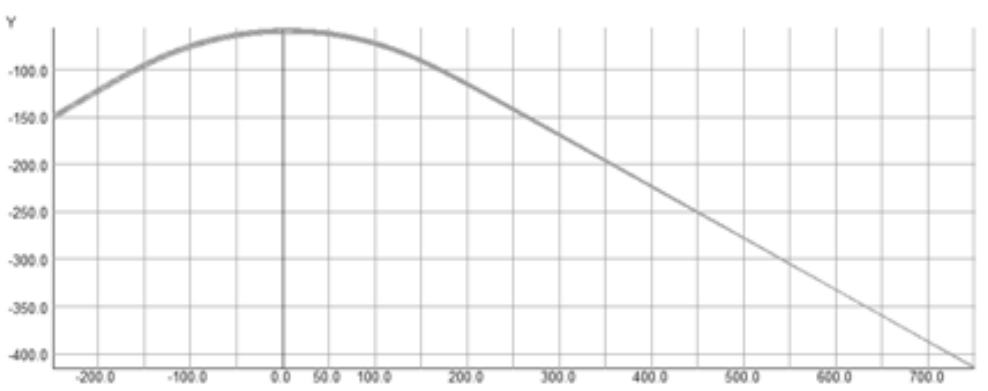

(a) Pemfokusan berkas radial

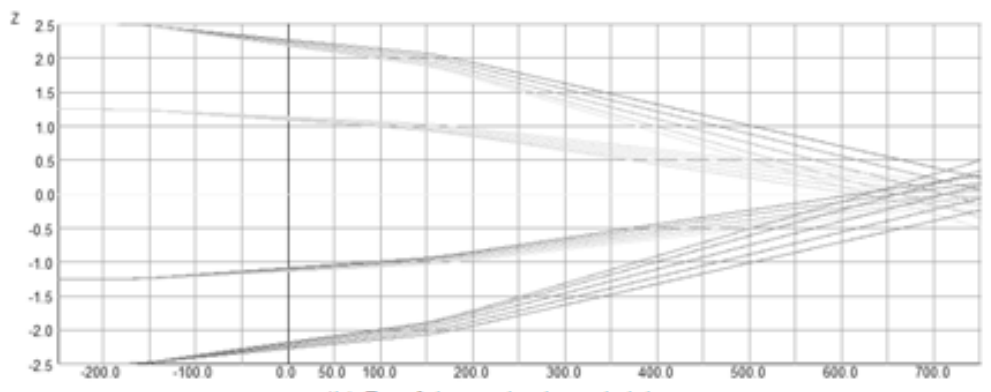

(b) Pemfokusan berkas aksial

Gambar 11. Pemfokusan berkas pada inti tipe $\mathrm{H}$

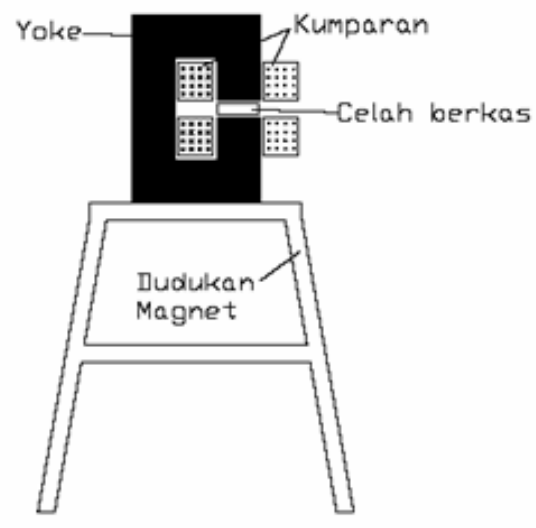

Gambar 12. Diagram magnet penganalisis 
Dari hasil iterasi penempatan posisi awal berkas, berkas ke-1 dan ke-2 hanya mengalami pemfokusan aksial sesuai dengan pemfokusan yang dihasilkan oleh sudut $\theta$ positif. Sedangkan pada berkas ke-3 selain terjadi pemfokusan aksial juga terjadi pemfokusan radial seperti ditunjukkan pada Gambar 11. Hal ini dikarenakan selain sudut $\theta$ bernilai positif, medan magnet membesar ke arah radial.

Magnet penganalisis dapat beroperasi dalam waktu yang panjang selama persyaratan operasi dapat terpenuhi. Adapun persyaratan operasinya adalah magnet harus selalu dalam keadaan bersih, diperlukan sistem pendingin yang memadai dan diperlukan arus yang stabil. Besar medan magnet mempengaruhi jenis partikel yang akan dibelokkan. Sedangkan medan magnet dipengaruhi oleh arus kumparan dan suhu inti besi dan kawat, sehingga arus dan suhu inti magnet diupayakan selalu konstan. Diagram dan tata letak magnet penganalisis ditunjukkan pada Gambar 12 dan 13.

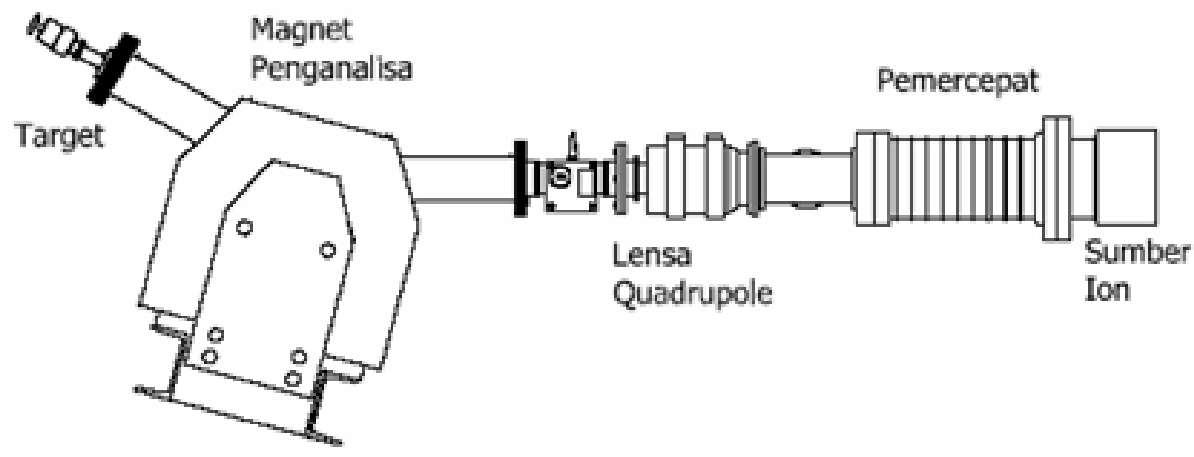

Gambar 13. Layout magnet penganalisis.

\section{KESIMPULAN}

Dari hasil rancang ulang ini diperoleh spesifikasi dari magnet penganalisis yang didesain mampu memisahkan partikel bermuatan dengan energi $150 \mathrm{keV}, \mathrm{m} / \mathrm{z}$ maksimum $8 \mathrm{amu}$, sudut pembelokan berkas $60^{\circ}$ dan daya yang dibutuhkan dalam magnet penganalisis sebesar 1,224 kwatt. Sedangkan hasil optimasi dari desain sebelumnya dapat dilakukan dengan mengubah bentuk inti magnet tipe $\mathrm{C}$ menjadi tipe $\mathrm{H}$ sehingga daya yang diperlukan lebih efisiensi 15,9\% dan menghasilkan medan magnet yang simetris. Selain itu untuk menghasilkan pemfokusan berkas yang baik, bentuk kutub magnet dibuat segi empat dengan posisi berkas yang masuk membentuk sudut $\theta$ positif $30^{\circ}$ dan lebih condong ke tepi kutub magnet dengan jarak 2,5 mm dari tepi kutub.

\section{DAFTAR PUSTAKA}

1. L.M. REDONDO, J. ROCHA, J.C. SOARES, Nuclear Instruments and Methods in Physics Research B 266 (2008) 3661-3666.

2. D. BERKOVITS, Y. BEN-DOV, I. BERKOVITS, C. BORDEANU, M. PAUL, Nuclear Instruments and Methods in Physics Research B 223-224 (2004) 233-236.

3. S.R. IN, Journal of the Korean Physical Society,49 (2006) S320_S323.

4. TAUFIK, R.S. DARMAWAN, S.SANTOSA, "Simulasi Awal Sistem Magnet Siklotron 13 MeV Menggunakan Superfish dan Opera-3D", Komputasi Dalam Sains dan Teknologi Nuklir 2010, Tangerang Selatan(2010) 173-184.

5. W. BEECKMAN, "Magnetic Design Improvement and Construction of The Large $90^{\circ}$ Bending Magnet of The Vertical Beam Delivery Line Of CNAO", Proceedings of EPAC (2008) 1782-1784.

6. Anonim, http://www.coilgun.info/theorymath/home.htm, 25 juni 2009.

7. MANDALA, G. RODRIGUESA, D. KANJILALA, P. BRODTB, F. BØDKER, Nuclear Instruments and Methods in Physics Research A 583 (2007) 219-227. 